\title{
Extra-anatomic aortic bypass for repair of type $A$ interrupted aortic arch associated with multiple aneurysms of the collateral circulation
}

\author{
NAG Stolf, MLP Sobral', A Terrazas, E Pires Jr., P Britto, GG Santos \\ From 23rd World Congress of the World Society of Cardio-Thoracic Surgeons \\ Split, Croatia. 12-15 September 2013
}

\section{Background}

Interrupted aortic arch in adults (18 years and older) is a rare condition which medical literature reports only few cases of isolated anomaly. If it is left untreated, $90 \%$ of the affected infants die at a median age of 4 days.

\section{Methods}

A 22 years old Asian woman with a history of cooling, swelling and pain of upper part of body during exercise, and cyanosis of left arm and both legs. At physical examination, she presented diminished pulses of the left arm and inferior limbs, and high blood pressure in the right arm. A Doppler showed switched flow in the left vertebral artery, and occlusion of left subclavian artery with a refilling through left vertebral and internal thoracic arteries. A thoracic CT scan diagnosed a type A interrupted aortic arch with very large aneurysms of collateral arteries. A single stage extra-anatomic procedure of ascending-to-descending thoracic aorta bypass grafting technique was performed through a median sternotomy and a posterior pericardial approach. Total occluding vascular clamps were used for the distal anastomosis of Dacron graft to the descending thoracic aorta. After the distal anastomosis, the left subclavian artery was ligated at its origin and the descending thoracic aorta, and proximally to the distal anastomosis, to prevent a rupture of the aneurysmatic collateral arteries.

\section{Results}

The procedure had no complications and the inferior limbs were warm and left arm presented a satisfactory perfusion without symptoms. After three months, a

* Correspondence: mlpsobral@uol.com.br

Unidade de Doenças Torácicas Stolf, Hospital Beneficência Portuguesa de São Paulo, São Paulo, Brazil thoracic CT scan showed excellent graft position and regression of the collateral arteries. After a year, the patient had no symptoms or complications.

\section{Conclusion}

Our patient presents a type A interrupted aortic arch with collateral aneurysms treated by an extra-anatomic aortic bypass that is an efficient surgical strategy for this particular type of presentation.

Published: 11 September 2013

\section{doi:10.1186/1749-8090-8-S1-P39}

Cite this article as: Stolf et al:: Extra-anatomic aortic bypass for repair of type A interrupted aortic arch associated with multiple aneurysms of the collateral circulation. Journal of Cardiothoracic Surgery 2013 8(Suppl 1): P39.
Submit your next manuscript to BioMed Central and take full advantage of:

- Convenient online submission

- Thorough peer review

- No space constraints or color figure charges

- Immediate publication on acceptance

- Inclusion in PubMed, CAS, Scopus and Google Scholar

- Research which is freely available for redistribution

Submit your manuscript at www.biomedcentral.com/submit
C Bïomed Central 